\title{
Overcoming African institutional voids: Market entry with networks
}

\author{
Kerry Chipp ${ }^{1,2}$, Albert Wöcke ${ }^{1}$ Carola Strandberg ${ }^{2}$ and Manoj Chiba ${ }^{1}$
}

\author{
${ }^{1}$ GIBS, University of Pretoria, South Africa \\ ${ }^{2}$ Luleå University of Technology (LTU) \\ *Author to which correspondence should be addressed
}

\author{
Chippk@gibs.co.za \\ Gordon Institute of Business Science \\ P O Box 787602. Sandton, South Africa, 2146
}

Kerry.chipp@ltu.se

Luleå tekniska universitet

Purpose: Literature on modes of entry has focussed on firm-level strategies. The predominant theories used are Institutional Theory and the resource based view. Using an alternate approach, network theory, the paper demonstrates an additional mode of entry: multiple firms entering together as an extension of an existing loose network, known as a bridging network. The extension of an external network across borders is an appropriate mode of entry in emerging markets with no preexisting networks or existing networks within a market that are weak, immature or missing.

Approach: A conceptual review, which develops four propositions, demonstrating that market entry with bridging networks may be the preferred mode of entry in the presence of institutional voids. Alternative modes may not be viable due to costs and risks associated with overcoming such voids.

Findings: Existing theory and case examples supports the contention that market conditions facilitate firms to enter as networks rather than as singular entities. These conditions are found in markets with institutional voids and explain the dominant form of business groups in many countries and the operation of loose strategic alliances in emerging markets. Network entry facilitates market access speed may allow for local ties to remain undeveloped or be a first step in building in-country networks.

Originality: This paper heeds to the call for a network ecosystem approach to market entry, arguing that firms may enter as a collective in subsistence and emerging markets which would explain the preponderance of business groups and loose alliances found.

Key words: Market entry, network theory, institutional voids 


\section{Introduction:}

Market entry literature traditionally focuses on market choice and market entry type and draws conclusions about the equity commitment, access to knowledge and resources and control between greenfields, joint ventures and acquisitions. Such literature has also been traditionally viewed from the perspective of, and predicated on, decisions of single firms, remaining atomistic (Hennart, 2009; Johanson and Vahlne, 1977; Johanson and Vahlne, 2009; Sasi and Arenius, 2008; Schweizer et al., 2010; Vahlne and Johanson, 2013; Vahlne, et al., 2012). In parallel, supply chain research, while exhorting social network analysis, has been critiqued for "centring their analysis on a single focal firm ... rather than taking a whole network perspective and looking for emergent properties of the network as a complete entity"(Sloane and O'Reilly, 2013, p. 622, emphasis added), with a subsequent calling for a "supply network ecosystem" perspective. Consequently, drawing these two streams of research together, this paper builds on Sloane and O'Reilly's (2013) view of a network ecosystem which has properties, resources and mutual action, of which market entry is one. This paper highlights the potential contribution of network theory to IB research in emerging markets (EM) and subsistence markets (SM) by arguing that market entry can occur by means of loose networks.

Hoskisson et al., (2000) view Institutional Theory as a key theory when studying EMs, and among strategy research on EMs it is the most predominant (Cuervo-Cazurra, 2006; Peng et al., 2008; Wright et al., 2005). Extant research on EMs has continued to focus on an institutional environment which is governed not only at the national level, but at transnational levels, for example bi- and multinational trade treaties (Meyer and Peng, 2016). While Meyer and Peng (2016) outline several areas of current and future concern, pertinent is their note on the growth of transnational supply chains, placing pressure on firms to integrate operations internationally. A supply chain perspective prepares the ground for conditions where network theory could add a great deal of value. Operational integration could encompass external network and therefore has implications for mode of entry to new markets. Greater operational integration requires a high degree of coordination and cooperation between firms outside of the formal organisational structures. In EMs coordination between firms within the targeted market is difficult since many firms operate in disparate industries and provide goods and services for different types of customers outside a single value chain. For example, resource firms in African markets extract minerals for export and the opportunities for integration of operations with suppliers of mining equipment or providers of banking services or logistics are unlikely. Preexisting partnerships then gain predominance.

The need for external partners is compounded in African markets by institutional voids. . Institutional voids are imperfect markets and institutions that are mainly found in EMs (Manikandan and Ramachandran, 2015). Institutional voids can include underdeveloped or absent capital markets, small or non-existent skilled labour pools, and poor regulatory environments (Khanna and Palepu, 1997). The view that individual firms can overcome institutional voids through developing capabilities or resources has long been described (e.g. Khanna and Palepu, 1997) and has been expanded to include business groups that use internal markets to overcome institutional voids (e.g. Manikandan and Ramachandran, 2015). When, for example, extractive industries are viewed in the light of institutional voids mining companies will require cooperation from other firms to overcome 
institutional voids such as access to capital, specialised labour and equipment, provided by firms of a type which will not be present in SMs and EMs.,

Consequently, we have noted a phenomenon in Africa where firms that have existing relationships extend them into new markets to overcome institutional voids. These relationships are not as formal or structured as those of business groups and can be described as a network of independent firms. Loose networks without strong ties are termed bridging networks (Laud et al., 2015). Firms in bridging networks cooperate to overcome institutional voids and thereby enable international expansion. The alternatives to cooperation would often require escalation of financial commitment in environments generally regarded as risky, as the majority of African countries are widely regarded as high-risk. High risk influences the decision to commit capital and repatriate profits and dividends (OECD, 2018). Our view of entry through bridging networks answers a call by Doh, Rodrigues, Saka-Helmhout and Makhija (2017) for new models of dealing with institutional voids. Overwhelmingly, current approaches offer three views on how firms deal with institutional voids: first firms either adapt to local conditions by internalising functions, second, firms shape or alter institutional conditions in the host country, or third, simply avoid environments with institutional voids altogether (Doh et al, 2017). We propose an alternative view, the loose network as a mode of entry.

Network theory is a new perspective for exploring modes of entry, but has been used as a moderator for the choice between JV or greenfields by individual firms (Dikova and Brouthers, 2016; Lo, Chiao, and $\mathrm{Yu}, 2016)$. Traditional network theory dealing with modes of entry has examined the position of the individual firm in the network; the utility of the network to access resources or knowledge and described formal bonded-networks (see for example Lo et al, 2016). This paper seeks to argue that the transfer of a loose (or bridging) external network of MNCs into a host country simultaneously is a hitherto undescribed mode of entry in itself and that an individual firm is merely one of the components of this network. A loose unbounded network is a network consisting of firms voluntarily cooperating with each other to overcome institutional voids in a host country and thereby reducing risk, cost and capital commitment.

The paper establishes this position in several stages: first the current firm level unit of analysis in the market entry literature is assessed, second there is a review of the dominant theory in order to establish the value of changing focus from Institutional Theory to network theory. The third area is the EM market conditions that make both Institutional Theory and networks useful, namely institutional voids and the lack of pre-existing networks in the host country. This discussion leads to four propositions. First, network theory can contribute beyond network development and partner selection, to become a means of market entry under conditions where there is a lack of any significant network within the host country; a characteristic found in markets with institutional voids. The partnership groups will depend on the area in which the void is most felt, such as either supply chain, capital or labour. Second, external network extension is mode of entry specifically for host markets that do not have existing local networks, or local networks that cannot support the MNCs and their supply chains. These external networks may interact with different level networks to establish 
themselves in the host country. Third, this mode of entry requires the network of MNCs to enter simultaneously. This implies that the external network includes MNCs with internationalisation experience, sufficient local knowledge, and resources that are transferable but rare in the host market. Fourth, subsequent to the entry by loose network, organisations may have the opportunity to update their own infrastructure to support their pre-existing network. All propositions underscore the need for a network. Working alone, an atomistic firm cannot fully service such a market due to gaps in supply chains and within market infrastructure, hence they act with a group of partners and it is thus proposed that network groups are a viable form of market entry. Africa presents both a spread of EMs and SMs and bears witness to the market entry of business groups as already formed networks.

\section{Existing Research on Market Entry and Networks}

Research on international market entry is primarily focused on three modes of entry: joint ventures (JV), acquisitions and greenfield investments (Hoskisson et al., 2004). Which entry mode to apply is of strategic importance for the exploration or exploitation of competitive advantages (Harzing, 2002; Hamel, 1991; Hagedoorn and Duysters, 2002, Chang and Rosenzweig, 2001; Hoskisson et al., 2004). Nevertheless, even as the strategic importance of entry modes is espoused, each mode is viewed from a firm perspective, remaining atomistic, rather than network ecosystem driven. Therefore, the prevailing view has led to hypothesising about which of the three modes of entry are most suitable to access resources and knowledge for the establishment of a subsidiary (JV, acquisition or greenfield), and researchers have had difficulty in matching modes of entry to market conditions (Dikova and Brouthers, 2016). Viewing entry from the standpoint of a single firm does not explain the phenomenon of a group of MNCs, that have an existing relationship, entering a market simultaneously and establishing a network in the host country. This phenomenon is observed in many subsistence economies in Africa, particularly from South African firms expanding into Sub-Saharan Africa.

This paper argues that there are market conditions where firms enter as a network and these conditions are accentuated within markets with institutional voids. These markets possess no strong pre-existing networks to join, conditions acutely characteristic in SMs but also in EMs. Not surprisingly, therefore, previous research has described the phenomenon of business groups in market entry. Groups have received much attention (see Khanna and Yafeh, 2015), and are framed as "hybrid organizational form between firm and market" (Khanna and Yafeh, 2015, p1). In network theory, bonding networks have strong ties, communicate frequently and have thick trust (Lee, 2009). Business groups are thus akin to bonded networks, with strong formalized ties. Strong ties and equity holdings have distinguished business groups from the bridging (or loose) networks of strategic alliances (Lee, 2009). Bridging networks are built on weak ties, common purposes, low degrees of communal identity, and no shared equity or management even as they share a common purpose (Holmes et al., 2018). We focus on bridging networks and loose ties and the shared purpose of market entry.

In their examination of the theoretical foundations of business research in EMs, Meyer and Peng (2016) acknowledge the importance of relationships and the presence of business groups, but they excluded alliances and loose networks. Business groups, however, are characterised as domestic, and relationships for market entry predominantly are internal collaboration by means of a JV, or relationship between the focal firm and national government (Holmes et al., 2018). The underlying assumption remains that local partners exist and the firm enters as a singularity after forming local 
relational partnerships. However, what if there are no significant firms with which to partner? We have observed less structured collaborations between firms to support each other and enable market entry into SMs and EMs in Africa.

\section{Emerging markets, Institutional voids and market entry}

The conditions of EM in general and Africa specifically inevitably require an assessment of country risk and therefore an emphasis on Institutional Theory. Uncertainty reduction has been paramount ever since (Hilmersson and Jansson, 2012) and firm competency in overcoming it has been reviewed (Li et al., 2013; Sandberg, 2013; Wang and Lestari, 2013) reflecting a resource based view (RBV).

Arnold and Quelch (1998) defined EM economies as dependent on fulfilling three criteria: first, low absolute level of economic development (GDP per capita) or balance between industry and agriculture activities; second, relatively elevated pace of economic development, third, government policies favouring free market economic liberalisation. Two distinct characteristics emerge: firstly, institutional voids, and, secondly, the process of economic liberalisation (Goncalves et al., 2012). Institutional Theory has been favoured for these markets, especially when dealing with national instability (Meyer and Peng, 2016) for many reasons: such countries are attractive because of high growth rates, the sustainability of which depends on the time the market has been open and how institutions have fared (Khanna and Palepu, 1997). Khanna and Palepu (1997) further argue that EMs, though heterogeneous, all share the feature of market failure, albeit to varying degrees, by failing to support basic business operations as a product of existing political and social systems. These deficiencies are found in product markets in the form of underdeveloped communication infrastructure, specialised intermediaries, ineffective or unreliable consumer-information organisations and watchdog organisations and few extrajudicial dispute resolution mechanisms (Khanna and Palepu, 1997). Further hurdles arise from inefficient labour markets due to a scarcity of skills and rigid labour laws. These increase uncertainty, risk and entail transaction costs. Regulatory issues arise since governments and their policies can vary greatly from those in developed countries, both in the extent of bureaucracy and involvement in business operations, in the consistency and predictability of decisions, regulations and degree of corruption (Zoogah et al., 2015). Due to these deficiencies and inefficient institutional mechanisms, such as financial reporting, problems arise in the capital market where uncertainties were historically thought to lead to higher risks, deterring investors (Khanna and Palepu, 1997).

Voids themselves differ in depth, type and degree depending on the level of development of the market, and in the context of EMs, market characteristics have been framed in terms of knowledge (Hilmersson and Jansson, 2012). While Parmigiani and Rivera-Santos (2015) report on five types of market voids, which can occur in any market, contracting voids have been viewed as particularly present in SMs, and IB scholars, have focussed primarily on capital markets, regulation and contracting voids (Stucchi et al., 2015). The loose networks that we have observed in Sub-Saharan Africa are a means to overcome this challenge. 
The relationships within and between organisations and institutions in an EM have been studied (Chang, et al., 2015), but not in terms of the initial market entry as a network; nor do they view increased bargaining power of a multiple firm coalition. Most authors highlight the nearly ubiquitous presence of business groups in EMs (for example: Becker-Ritterspach and Bruche, 2012; Khanna and Yafeh, 2015; Manikandan and Ramachandran, 2015; Stucchi et al., 2015) but not the less structured and informal networks that operate in the most risky countries in Africa.

\section{Voids and pre-existing networks}

Previous research on firms cooperating to overcome voids has focussed on business groups and their interaction with existing local firms networks (e.g. Stucchi et al, 2015). However, studies on Chinese FDI in Africa have identified an alternative network model whereby Chinese firms commit large resources and interact minimally with local firms, importing their labour and equipment needs (Burke, 2007; Chen and Orr, 2009; Corkin, 2007). This reliance on a Chinese network rather than a local one has been ascribed to immaturity in Chinese internationalisation (Song, 2011) rather than a strategy of network entry. A network-perspective and renewed look at where learning can take place may change this perception of China (Song, 2011).

A cooperative network may serve to overcome market entry impediments caused by voids: infrastructure and supply chains are often part of a void and represent a gap in need of filling, particularly when local firms are not present (Parmigiani and Rivera-Santos, 2015). The implication is that opportunities for development through an "establishment chain" within the market is not fully possible, similar to Burke's (2007) observation in different African countries. The severity of an institutional voids impact on supply chains in SMs is largely determined by which parts are located within the market and which outside (Parmigiani and Rivera-Santos, 2015). SMs could be conceived as the least developed of EMs where strong internal business groups have yet to form (Stucchi et al., 2015). Thus the supply chain has been highlighted as a challenge requiring greater attention (Viswanathan and Venugopal, 2015) and approaches tend to be within country and based on the later formation of networks (Kolk and Lenfant, 2015). For example Parmigiani and Rivera-Santos' (2015) stress the need to build networks within country to patch the network void. These authors report that more complex activities with high void impact are commonly located outside the market while simple activities or short-term exchanges can be located within (Parmigiani and Rivera-Santos, 2015).

Supply chain network extension can be illustrated through the internationalisation experience of Imperial Logistics. Imperial Logistics, a division of the larger Imperial Holdings, positions itself as an end to end provider of logistics and route to market processes, which includes logistics, route to market and consumer conversion. The company terms these "get me there," "sell my product" and "establish my brand". Partners in their network include international MNCs (Nestle, Spar, Johnson \& Johnson, P\&G, Walmart, Mondelez, BAT, GSK, among others) and EMCs from South Africa (Glencore, Tiger Brands, Pick ' $n$ Pay and Nampak). Imperial identifies the entire route to market process as challenging in Africa, thus they partner with other MNCs when these companies expand into markets 
such as Ghana and Nigeria. Imperial in turn was able to build a local presence in many of these countries as part of a positive feedback loop and now enjoys a substantial network across the continent. The company makes it clear that they do not enter markets ahead of their partners, stating that they do not generally do greenfield operations (Cokayne, 2018). Transporting fast moving consumer goods across the continent requires deep relationships and capabilities to deal with institutional challenges of customs and duties, the management of foreign exchange and maintenance of a fleet of vehicles in SMs. Institutional voids in these countries are largely due to a lack of local firms that have this capability and the lack of infrastructure that makes the development of this capability costly and risky for other firms in the network. Imperial Logistics also benefits from its ability to provide cross-border transport and some protection from the currency volatility associated with African countries.

Proposition 1: External network extension is an appropriate alternative mode of entry for markets that feature institutional voids in knowledge, supply chain or labour.

Rivera-Santos, et al., (2012) argue that in EMs partnerships include multiple partners from multiple sectors to compensate for the different institutional voids. These collaborations will substitute formal contracts, equity and other governance mechanisms with informal contracts. They further state that organisations originating from outside the EM will rely more on the formal, regulative institutions while organisations from within the EM will rely more on the informal, normative and cognitive institutions (Rivera-Santos et al., 2012).

From an MNC view, Parmigiani and Rivera-Santos (2015) divide the voids in two types, first dyadic, such as product or contracting voids, which may be remedied by leveraging relationships, social norms and reputation as a governing mechanism. Secondly, network institutional voids, like capital and regulatory voids, where there may be a variety of partners such as private, public or non-profit organisations to work with, and the aim is to strengthen local partners. The second approach is closer to other marketing scholars such as Kolk and Lenfant (2015) and Viswanathan and Venugopal (2015). Parmigiani and Rivera-Santos (2015) describe two approaches to filling the voids, first, a corporate approach, in which the firm fills the voids on its own by creating a network of small, local firms, nonprofit organisations and others for each step of the chain. In the second approach, termed the agency approach, the MNC does not fill the void directly but seeks a partner to solve these problems across the supply chain. Most importantly, Parmigiani and Rivera-Santos (2015) note that the agency approach speeds up market entry, citing pre-existing ties that the large partner has within the market. Close inspection of Parmigiani and Rivera-Santos (2015), however, demonstrates no explicit realisation that entering as a network may solve these voids or that cooperation in one market may lead to cooperation when entering another; and considerably quicken entry. This is illustrated by the case of Barloworld Equipment.

Barloworld is a South African MNC with operations in 26 countries and is the Caterpillar dealer in 12 southern African countries and Siberia, Spain, Portugal and Andorra. Barloworld is one of Caterpillar Inc's five top global dealers and has been the South African Caterpillar license holder in South Africa since 1927 where its customers are primarily mining companies. Extensive specialised skills and infrastructure were required to support customers using Caterpillar equipment, including satellite 
monitoring of equipment and ensuring the shortest equipment downtime possible. Barloworld had built an extensive support infrastructure in South Africa that included training centres for operators and technicians that complied with the toughest US standards. In addition Barloworld offered financing solutions to customers and provided an advanced warehousing system for spare parts. Moreover Barloworld was able to repair and rebuild Caterpillar equipment for customers thereby improving reliability and reducing operating costs.

In 1994 Barloworld was granted Caterpillar dealership franchises in Zambia, Malawi, Mozambique and Angola. This coincided with the end of apartheid in South Africa and an unprecedented expansion by South African companies into Africa, particularly mining firms. At that stage mining firms were faced with the prospect of importing and operating their own heavy equipment. The greatest problem for mines was downtime, which was inevitable without trained operators, technicians, and freely available spares and support. Barloworld was able to support the mining companies, most of whom it had existing relationships with in South Africa, to build operations in first in Zambia and the other countries. The subsidiaries included training facilities to train operators and technicians up to Caterpillar Inc standards. Capabilities that did not exist in these countries until Barloworld's investment. Relationships with existing customers allowed Barloworld to build subsidiaries and expand at a rate that they knew the customers could support; knowledge of the customers also allowed Barloworld to tailor their infrastructure according to what was required. A further benefit was that the existing relationships could overcome contractual voids and uncertainties related to foreign exchange volatility and repatriation of capital (Barloworld 2018; Naude, 2012).

The Barloworld example leads to our second proposition:

Proposition 2: The external network may play a role in building networks in the host country through extension. This network will not be confined to intra-firm level and may extend to government and local community levels.

\section{Network potential as a Mode of Entry}

As regulations play a diminished role in SMs, informal institutions dominate (Rivera-Santos et al., 2012). These institutions are represented to be firstly, bound by ethnic, familial, religious and other ties; secondly; these ties are stronger within a community than outside of it, and third, ties are local rather than international in nature (Rivera-Santos et al., 2012). This leads to a complexity of relations between communities, government and business in SMs which are atypical to other markets and are therefore one of the greatest challenges for market entry for outsiders. Closing institutional voids would require business relationships with business partners who reliably service the network. Thus, this paper argues that network entry requires simultaneous entry of a set of firms accustomed to operating in conjunction but does not substitute for local relations with communities and governments.

We argue that a network approach allows a participant in that network to access multiple points that would otherwise be inaccessible to an outside firm entering a market alone. Belonging to a network reduces transaction costs by reducing uncertainties and inefficiencies that would otherwise occur if 
operating outside the network in a SM or EM. These activities can be described as "piggybacking". Terpstra and Yu (1990, p.53) define piggybacking as "closer than arm's length but short of a formal joint venture or merger" and refers to carrying something on one's back. Piggybacking is commonly adopted by firms in the early stages of internationalisation into a country when it is not feasible to invest directly abroad due to cost or risk. This would also apply in countries that have institutional voids that the firm cannot overcome on their own, or without great expense and risk. However, piggybacking also assumes using another firm's existing local network (Gubik and Karajz, 2014). The extension of the network needs to occur simultaneously with other firms to overcome institutional voids. This is illustrated with the case of Standard Bank of South Africa.

Standard Bank operates in 19 African countries, with most of its expansion in Africa occurring after the 2008 global crisis. Prior to 2008, Standard Bank had operated in South Africa with subsidiaries in Namibia and Botswana, but with representatives in Mozambique and Angola. Expansion was through acquisition of small banks and rebranding them. In about 2000, Standard Bank began to acquire businesses in markets such as Turkey, Argentina, Hong Kong and Russia. The 2008 global financial crisis led to huge losses in those markets and Standard Bank realised that it did not have the resources, financial or human, to scale those businesses and it should focus its attention on Africa, where it felt more comfortable. However, operating in Africa post-2008 became more difficult for international banks due to new capital market requirements and regulations. Standard Bank had to comply with international standards to access investors in the international financial markets and spread risks that originated from customers from EMs. However, the new focus on Africa would mean that Standard Bank would be competing against local banks that did not need to meet these stringent new regulations. With the new regulations Standard Banks previous strategy of buying local banks would expose it to greater risks and costs than before the post-2008 crisis. Consequently Standard Bank chose to follow a much simpler and less capital and liquidity intensive strategy for expansion into Africa. Standard Bank, like most large banks globally, consists of two main businesses, personal and business banking (PBB), and corporate and investment banking ( $\mathrm{ClB}$ ). Standard Bank's new expansion model was based on leading with $\mathrm{CIB}$ offerings to large customers, and when the operation was sufficiently established, it would expand its offerings into PBB. PBB offerings required the roll out of branches, infrastructure and IT support. The success of a PBB expansion would need substantial local knowledge and investment in the right places. This strategy had the advantage of limiting risk and exposure of the rest of Standard Bank to countries with poorly developed banking regulations. This two-stage model required Standard Bank to join their large corporate customers when they entered a new market and build their presence while supporting them. These clients required a local presence for services such as cash management, foreign exchange and local payments. Standard Bank offered them the opportunity to consolidate their banking and extend the relationships with the bank that was well-established in South Africa. The risk to Standard Bank was reduced as their customers already complied with the international banking regulations and Standard Bank understood the risk profiles of these customers.

The post-2008 global financial regulations required an upgrading of processes and capabilities that MNCs had to meet but were not available in many of the Sub-Saharan African countries where Standard Bank's South African customers operated. Standard Bank overcame this through acquisition of small local banks and injected IT infrastructure and skills into those acquisitions to support the network of corporate clients (Paul, 2012). When the local operations were sufficiently stable, they 
would form the basis of expansion into retail banking and PBB. Standard Bank also benefitted from network relationships with customers such as MTN, the giant telecommunications operator from South Africa, when Standard Bank and MTN offered joint products and banking services to communities that did not have access to ATMs and cash services.

The example of Standard Bank supports two propositions:

Proposition 3: The network mode of expansion often requires that multiple network members enter the market simultaneously or in short succession.

Proposition 4: The network mode of entry may include the updating of existing infrastructure to support the existing network to overcome institutional voids.

\section{Conclusions}

Extant research on modes of entry focus on the choices between acquisition, joint venture or greenfield modes (Dikova and Brouthers, 2016) and business groups (Manikandan and Ramachandran, 2015). A network perspective has enabled us to identify another mode of entry, extending an external network. This mode of entry differs from previously identified modes of entry as multiple firms loosely cooperate to enter a market simultaneously with the objective of establishing a new local network. This new local network is a joint solution for MNCs to overcome voids in the host market. This choice has implications for a participating MNC for further expansion and cooperation with the network within the host country. A firm participating in this network may decide to acquire a local firm to partially fill a void, or it may transfer resources and labour into the new market. This is not the same as a greenfield mode of entry as the MNC will not be seeking to build a market but will fit into an existing network (Barloworld). Once established the firm may extend its presence beyond the market through network expansion (Imperial Logistics). It is reasonable to expect the new network to be extended to other networks as it is localised (all three examples Imperial Logistics, Barloworld and Standard Bank). Policy makers would be interested in this phenomenon as it could lead to significant spillover effects such as the establishment of new industries while overcoming voids. This is beyond the scope of this paper but is an area for further investigation. A further area for further investigation is the nature of the relationships between the participants in this network and the relationships between the network and local stakeholders such as government and communities. In many EMs MNCs are required to include local participants in their value chains as a condition for FDI.

\section{References}

Arnold, D.J. and Quelch, J.A. (1998), "New strategies in emerging markets", MIT Sloan Management Review, Massachusetts Institute of Technology, Vol. 40 No. 1, p. 7.

Barloworld (2018). Barloworld Equipment. (Available at https://www.barloworld-equipment.com, Accessed 16 October 2018)

Becker-Ritterspach, F. and Bruche, G. (2012), “Capability creation and internationalization with 
business group embeddedness - the case of Tata Motors in passenger cars", European Management Journal, Vol. 30 No. 3, pp. 232-247.

Burke, C. (2007), "China's Entry into Construction Industries in Africa Tanzania and Zambia as Case Studies", China Report, Sage Publications, Vol. 43 No. 3, pp. 323-336.

Chang, J., Bai, X. and Li, J.J. (2015), "The Influence of Institutional Forces on International Joint Ventures' Foreign Parents' Opportunism and Relationship Extendedness.", Journal of International Marketing, American Marketing Association, Vol. 23 No. 2, pp. 73-93.

Chang, S.-J., \& Rosenzweig, P. M. (2001). The choice of entry mode in sequential foreign direct investment. Strategic Management Journal, 22(8), 747-776.

Chen, C. and Orr, R.J. (2009), "Chinese contractors in Africa: Home government support, coordination mechanisms, and market entry strategies", Journal of Construction Engineering and Management, American Society of Civil Engineers, Vol. 135 No. 11, pp. 1201-1210.

Cokayne, R. (2018), "Imperial Logistics targets 'big' opportunities in Africa”, Business Report, available at: https://www.iol.co.za/business-report/companies/imperial-logistics-targets-bigopportunities-in-africa-16716071.

Corkin, L. (2007). The strategic entry of China's emerging multinationals into Africa. China Report, 43(3), 309-322.

Cuervo-Cazurra, A. (2006), "Business groups and their types", Asia Pacific Journal of Management, Vol. 23 No. 4, pp. 419-437.

Doh, J., Rodrigues, S., Saka-Helmhout, A., \& Makhija, M. (2017). International business responses to institutional voids. Journal of International Business Studies. https://doi.org/10.1057/s41267017-0074-z

Dikova, D., \& Brouthers, K. (2016). International Establishment Mode Choice: Past, Present and Future. Management International Review, 56, 489-530.

Goncalves, M.X., Campos Filho, L.A.N., Casanova, L. and Esteban Jardim, P. (2012), “Institutional Theory, Membership in Business Groups and the Internationalization of Brazilian Multinationals", INSEAD Working Paper.

Gubik, A.S. and Karajz, S. (2014), "The Choice of Foreign Market Entry Modes: The Role of Resources and Industrial Driving Forces1", Entrepreneurial Business and Economics Review, Cracow University of Economics, Vol. 2 No. 1, p. 49.

Hagedoorn, J., \& Duysters, G. (2002). External sources of innovative capabilities: the preferences for strategic alliances or mergers and acquisitions. Journal of Management Studies, 39(2), 167188.

Hamel, G. (1991). Competition for competence and interpartner learning within international strategic alliances. Strategic Management Journal, 12(S1), 83-103.

Harzing, A.-W. (2002), "Acquisitions versus greenfield investments: International strategy and management of entry modes", Strategic Management Journal, Wiley Online Library, Vol. 23 No. 3, pp. 211-227.

Hennart, J.-F. (2009). Down with MNE-centric theories! Market entry and expansion as the bundling of MNE and local assets. Journal of International Business Studies, 40(9), 1591-1591. 
https://doi.org/10.1057/jibs.2009.81

Hilmersson, M. and Jansson, H. (2012), "Reducing uncertainty in the emerging market entry process: on the relationship among international experiential knowledge, institutional distance, and uncertainty", Journal of International Marketing, American Marketing Association, Vol. 20 No. 4, pp. 96-110.

Holmes, R.M., Hoskisson, R.E., Kim, H., Wan, W.P. and Holcomb, T.R. (2018), "International strategy and business groups: A review and future research agenda", Journal of World Business, Vol. 53 No. 2, pp. 134-150.

Hoskisson, R.E., Eden, L., Lau, C.M. and Wright, M. (2000), "Strategy in emerging economies", Academy of Management Journal, Academy of Management, Vol. 43 No. 3, pp. 249-267.

Hoskisson, R.E., Kim, H., White, R.E. and Tihanyi, L. (2004), “A Framework for Understanding International Diversification by Business Groups from Emerging Economies", Advances in International Management 16, available at:https://doi.org/10.1016/S0747-7929(04)16008-3.

Johanson, J. and Vahlne, J.-E. (2009), "The Uppsala internationalization process model revisited: From liability of foreignness to liability of outsidership", Journal of International Business Studies, Vol. 40 No. 9, pp. 1411-1431.

Johanson, J.J.J. and Vahlne, J.-E.J. V. (1977), "The Internationalization Process of the Firm-A Model of Knowledge Development and Increasing Foreign Market Commitments", Journal of International Business Studies, Vol. 8 No. 1, pp. 23-32.

Khanna, T. and Palepu, K. (1997), "Why Focused Strategies May Be Wrong for Emerging Markets.", Harvard Business Review, Vol. 75 No. 4, pp. 41-51.

Khanna, T. and Yafeh, Y. (2015), "Business groups in emerging markets: Paragons or parasites?", Review of Economics \& Institutions/Economia, Societa e Istituzioni, Vol. 6 No. 1.

Kolk, A. and Lenfant, F. (2015), "Cross-Sector Collaboration, Institutional Gaps, and Fragility: The Role of Social Innovation Partnerships in a Conflict-Affected Region.", Journal of Public Policy \& Marketing, American Marketing Association, Vol. 34 No. 2, pp. 287-303.

Laud, G., Karpen, I.O., Mulye, R. and Rahman, K. (2015), "The role of embeddedness for resource integration: Complementing S-D logic research through a social capital perspective", Marketing Theory, Vol. 15 No. 4, pp. 509-543.

Lee, R. (2009), "Social capital and business and management: Setting a research agenda", International Journal of Management Reviews, Vol. 11 No. 3, pp. 247-273.

Li, T., Seaton, B. and Tsalikis, J. (2013), "Emerging customers, market knowledge competence, and investor transition: The experience of MNCs in China.", Journal of Global Marketing, Taylor \& Francis, Li, Tiger, Department of Marketing, Chapman Graduate School of Business, Florida International University, University Park, RB302B, Miami, FL, US, 33199, Vol. 26 No. 3, pp. 115136.

Lo, F-Y., Chiao, Y-C \& Chwo-Ming, J.Y. (2016). Network and Institutional Effects on SMEs' Entry Strategies. Management International Review, 56, 531-563.

Manikandan, K.S. and Ramachandran, J. (2015), "Beyond institutional voids: Business groups, incomplete markets, and organizational form", Strategic Management Journal, John Wiley \& Sons, Ltd, Vol. 36 No. 4, pp. 598-617. 
Meyer, K.E. and Peng, M.W. (2016), "Theoretical foundations of emerging economy business research", Journal of International Business Studies, Palgrave Macmillan, Basingstoke, Vol. 47 No. 1, pp. 3-22.

Naudé. C. (2012). Chapter 8 Barloworld: Driving Change Beyond Borders. In: Makura, M. (ed) (2012). Going Global: Insights from South Africa's Top Companies. MME Media: Johannesburg South Africa. (215-242).

OECD (2018). Country Risk Classification. (available at http://www.oecd.org/trade/xcred/crc.htm, accessed 16 October 2018)

Parmigiani, A. and Rivera-Santos, M. (2015), "Sourcing for the base of the pyramid: Constructing supply chains to address voids in subsistence markets", Journal of Operations Management, Vol. 33-34, pp. 60-70.

Peng, M.W., Wang, D.Y.L. and Jiang, Y. (2008), "An institution-based view of international business strategy: A focus on emerging economies", Journal of International Business Studies, Nature Publishing Group, Vol. 39 No. 5, pp. 920-936.

Rivera-Santos, M., Rufin, C. and Kolk, A. (2012), "Bridging the institutional divide: Partnerships in subsistence markets", Journal of Business Research, Vol. 65 No. 12, pp. 1721-1727.

Sandberg, S. (2013), "Emerging market entry node pattern and experiential knowledge of small and medium-sized enterprises.", International Marketing Review, Emerald Group Publishing Limited, Sandberg, Susanne, Vol. 30 No. 2, pp. 106-129.

Sasi, V. and Arenius, P. (2008), "International new ventures and social networks: Advantage or liability?", European Management Journal, Vol. 26 No. 6, pp. 400-411.

Schweizer, R., Vahlne, J.-E. and Johanson, J. (2010), "Internationalization as an Entrepreneurial Process", Journal of International Entrepreneurship, U Gothenburg, Vol. 8 No. 4, pp. 343-370.

Sloane, A. and O'Reilly, S. (2013), “The emergence of supply network ecosystems: a social network analysis perspective", Production Planning \& Control, Taylor \& Francis, Vol. 24 No. 7, pp. 621639.

Song, H. (2011), "Chinese private direct investment and overseas Chinese network in Africa", China \& World Economy, Wiley Online Library, Vol. 19 No. 4, pp. 109-126.

Stucchi, T., Pedersen, T. and Kumar, V. (2015), "The Effect of Institutional Evolution on Indian Firms' Internationalization: Disentangling Inward- and Outward-Oriented Effects", Long Range Planning, Vol. 48 No. 5, pp. 346-359.

Terpstra, V. and Yu, C.-M.J. (1990), "Piggybacking: a quick road to internationalisation", International Marketing Review, MCB UP Ltd, Vol. 7 No. 4.

Vahlne, J.-E. and Johanson, J. (2013), "The Uppsala model on evolution of the multinational business enterprise - from internalization to coordination of networks.", International Marketing Review, Vol. 30 No. 3, pp. 189-210.

Vahlne, J.-E., Schweizer, R. and Johanson, J. (2012), "Overcoming the Liability of Outsidership-The Challenge of HQ of the Global Firm", Journal of International Management, Vol. 18 No. 3, pp. 224-232.

Viswanathan, M. and Venugopal, S. (2015), "Subsistence Marketplaces: Looking Back, Looking 
Forward.", Journal of Public Policy \& Marketing, American Marketing Association, Vol. 34 No. 2, pp. 228-234.

Wang, K.-J. and Lestari, Y.D. (2013), "Firm competencies on market entry success: Evidence from a high-tech industry in an emerging market.", Journal of Business Research, Vol. 66 No. 12, pp. 2444-2450.

Wright, M., Filatotchev, I., Hoskisson, R.E. and Peng, M.W. (2005), "Strategy research in emerging economies: Challenging the conventional wisdom*", Journal of Management Studies, Wiley Online Library, Vol. 42 No. 1, pp. 1-33.

Zoogah, D.B., Peng, M.W. and Woldu, H. (2015), "Institutions, Resources, and Organizational Effectiveness in Africa", Academy of Management Perspectives, Vol. 29 No. 1, pp. 7-31. 